\title{
Current state and new aspects of fertility preservation surgery in some oncogynaecological diseases
}

\section{Aktualny stan wiedzy i nowe doniesienia z zakresu chirurgii zachowującej płodność w wybranych schorzeniach onkoginekologicznych}

\author{
Yavor Kornovski ${ }^{1}$, Yonka Ivanova ${ }^{1}$, Stoyan Kostov ${ }^{1}$, Stanislav Slavchev ${ }^{1}$, Angel Danchev Yordanov² \\ ${ }^{1}$ Medical University - Varna; Obstetrics and Gynaecology Clinic, St. Anna University Hospital, Varna, Bulgaria \\ ${ }^{2}$ Department of Gynaecological Oncology, Medical University Pleven, Pleven, Bulgaria
}

Key words: granulosa cell tumours, cervical cancer, epithelial borderline ovarian tumours, fertility preservation surgery.

Słowa kluczowe: guzy z komórek ziarnistych, rak szyjki macicy, nowotwory nabłonkowe jajnika o granicznej złośliwości, chirurgia zachowująca płodność.

\begin{abstract}
Preservation of reproductive function in young patients with uncompleted or unrealized reproductive plans in some malignant tumours of the female reproductive system has been a subject of study for many years, especially with the advances in assisted reproductive technologies. The main neoplasms that affect women in childbearing age are cervical cancer and ovarian tumours. In the current survey the novelties in the literature will be presented regarding the fertility preservation surgery in cervical cancer with size of tumour between 2 and $4 \mathrm{~cm}$, granulosa cell ovarian tumours, and epithelial borderline ovarian tumours
\end{abstract}

\section{Streszczenie}

Zachowanie funkcji rozrodczych u młodych pacjentek z niektórymi nowotworami złośliwymi układu rozrodczego, które nie zakończyły jeszcze lub nie zrealizowały planów reprodukcyjnych, jest przedmiotem badań już od wielu lat, zwłaszcza w zakresie postępów w technologiach wspomaganego rozrodu. Do głównych nowotworów występujących u kobiet w wieku rozrodczym należą rak szyjki macicy oraz rak jajnika. W poniższym opracowaniu przedstawiono najnowsze dane z piśmiennictwa dotyczącego zabiegów chirurgicznych zachowujących płodność u pacjentek z nowotworem szyjki macicy o wielkości zmiany od 2 do $4 \mathrm{~cm}$, guzami jajnika z komórek ziarnistych oraz nowotworami nabłonkowymi jajnika o granicznej złośliwości.

The possibility of sparing the childbearing functions in young nulliparous women, or women, who have reproduction plans, with different locations of malignant tumours of the female reproductive system (FRS), has been the subject of many scientific studies for some decades. In the current survey, we consider the present-day state of literature and modern achievements of science regarding this surgery in some oncogynaecological diseases, namely the following:

I. Preservation of childbearing functions in young women with cervical cancer (CC) of IB1 and IB2 stage (FIGO classification of 2018; size of tumour of up to $4 \mathrm{~cm})$.

II. Novelties in the fertility preservation surgery in hormone-producing tumours (sex cord tumours (SCT)), and more specifically granulosa cell tumours (GCT) of juvenile type fertility preservation surgery (FPS) in epithelial borderline ovarian tumours (BOTs).
III. Possibilities for preservation of childbearing functions in young women with CC of IB1 and IB2 stage (FIGO classification of 2018; size of tumour of up to $4 \mathrm{~cm}$ ).

It was found that up to $40 \%$ of the early invasive $\mathrm{CC}$ is encountered in women at age under 40 years, who desire preservation of their childbearing potential [1]. Additionally, more women postpone their reproductive plans, in view of social and economic factors and pursuing their careers. That is why the interest in organ preservation surgery and preservation of fertility potential in women with early invasive CC has increased in the last decades.

The requirements for FPS in CC include the following: histological variant - squamous cell carcinoma or adenocarcinoma; size of the tumour lesion less than $4 \mathrm{~cm}$; absence of lymph node metastases; and lymphovascular invasion [2, 3]. 
Table 1. Oncological and reproductive results after performing ART

\begin{tabular}{|lcc|}
\hline $\begin{array}{l}\text { Abdominal radical } \\
\text { trachelectomy }\end{array}$ & $\begin{array}{c}\text { Relapses } \\
(\%)\end{array}$ & $\begin{array}{c}\text { Pregnancies } \\
(\%)\end{array}$ \\
Wethington (2012) [8] & 4 & 74 \\
Nishio (2009) [9] & 10 & 14 \\
Li (2011) [10] & 0 & 20 \\
Muraji (2012) [11] & 0 & 10 \\
Saso (2012) [12] & 10 & 30 \\
Pareja (2008) [13] & 0 & 50 \\
Ungar (2005) [6] & 0 & 30 \\
Totally & 3.7 & 39 \\
\hline
\end{tabular}

There is no difference in the frequency of relapses between adenocarcinoma and squamous cell carcinoma, but such a difference exists for the more aggressive histological variants as neuroendocrine and clear cell carcinomas, and that is why they are assumed as contraindications for FPS [2-4].

The organ preservation surgery in CC includes several surgical approaches, based on the radical trachelectomy, which can be performed in several ways: vaginal radical trachelectomy (VRT), abdominal radical trachelectomy (ART), laparoscopic radical trachelectomy (LRT), robot-assisted radical trachelectomy (RART), minimally invasive procedures - simple trachelectomy, wide conisation.

The ART ensures the greatest radicality regarding the paracervix, while the vaginal techniques have limited radicality and are more conservative to that tissue [4]. In the last few years more conservative techniques - such as simple trachelectomy and wide conization have been imposed. Regardless of the choice of operative technique, the selection of patients begins with performing laparoscopic lymph node dissection with the use of indocyanine green as a marking agent according to European Society of Gynaecological Oncology (ESGO) guidelines [4].

The size of the tumour lesion is the main factor for the choice of operative technique for FPS [4]. Vaginal radical trachelectomy is recommended for tumour lesions up to $2 \mathrm{~cm}$, or vaginal simple trachelectomy (VST) in selected cases with low risk. ESGO guidelines recommend ART in tumour lesions from 2 to $4 \mathrm{~cm}$ (IB2, 2018).

The technique of ART was described for the first time in 1997 by Smith et al., while the first series of 33 operated women with CC was published in 2005 $[5,6]$.

The advantages of ART in comparison with VRT, which are emphasized, are as follows:

- it does not require any skills in vaginal surgery or laparoscopic lymph node dissection,

- no expensive equipment is required,
- the learning curve is brief,

- the technique is similar to that of radical hysterectomy (RH), and it has gained wide popularity,

- it ensures greater radicality with respect to the paracervix and provides the possibility for application of nerve-preserving techniques.

In the beginning the ligation of uterine arteries were included in the description of the procedure $[6,7]$.

A survey from different authors is presented in Table 1, which synthesizes the oncological results - on one side - and the reproductive results (frequency of pregnancies occurred) - on the other. Data from different authors show that ART ensures excellent oncological safety, but the reproductive results show an average frequency of pregnancy occurring of 39\% [6-13].

There are many studies in the medical literature that demonstrate unsatisfactory reproductive results (not only the frequency of pregnancies, but also the frequency of incomplete carrying of foetus - abortions and premature parturitions) for ART, compared to VRT and VST $[14,15]$. The survey data of Schneider et al. correlate different techniques with each other with respect to the frequency of pregnancies, and they found $15 \%, 30 \%$, and $72.5 \%$ occurrence of pregnancies after, respectively, ART, VRT, and VST [14]. Therefore, the more sparing the surgical intervention is to the paracervical tissue, the better the reproductive results. Thus, arises the main question: Could some of these fertility preservation techniques be applied in order to achieve optimal reproductive results (occurrence of pregnancy, carrying and parturition of viable foetus) without compromise of the oncological results? The use of techniques as VRT, VST, and conization after neoadjuvant chemotherapy (NCT) in cervical tumour lesions with sizes from 2 to $4 \mathrm{~cm}$ can be an alternative to ART with respect to oncological safety. The purpose of NCT is reduction of the size of tumour (tumour downstaging), and even its removal in order to ensure radicality of the subsequent intervention. This is a working hypothesis, which is a subject of future studies, and it has been launched with increasing conviction during the last few years [15]. Plante, a leading researcher in this field, set - even in 2013 - the future directions and tendencies of fertility preservation options in tumour lesions of the uterine cervix with sizes of up to $4 \mathrm{~cm}$. The aspiration is directed towards reducing the radicality and ensuring the oncological safety by means of NCT [16].

Bentivegna performed a survey of medical literature about 6 techniques for FPS in 2016, while correlating oncological and reproductive results [17]. The same author - in the same year - published in the journal "Fertility and Sterility" a survey of 2700 patients, who were subject to FPS by means of different techniques, and analysed the frequency of incomplete carrying of the foetus. The lowest percentage of incomplete carrying of the foetus (15\%) was seen in the group of NCT and conization (simple trachelectomy). 
The author concluded that when the oncological results for tumours with size up to $4 \mathrm{~cm}$ (IB1 - FIGO 2008) were similar, the reproductive results had to be taken into consideration [18].

A meta-analysis from 2019 by Van Kol et al., including 338 patients, juxtaposes ART to NCT, followed by VRT. In $70 \%$ of those who desired conception, after NCT and VRT, pregnancy occurred, and $63 \%$ of them gave birth to living, full-term foetuses. For comparison, only $21 \%$ conceived after ART, and in just $42 \%$ of them pregnancy ended with parturition of a living, full-term foetus. The oncological results in both groups did not show any statistically significant difference [19].

All those surveys, studies, and analyses approve NCT as a method preserving fertility in CC. The question of what type of conservative intervention should be performed after NCT is important: VST, VRT, or conization. The collective of Prof. Ignace Vergote from the Oncogynaecological Centre in Leuven, Belgium recommends performing first of all conization, and - in the rare cases of incomplete histological response - trachelectomy or radical hysterectomy [20]. In confirmation of this recommendation, up-to-date results from a prospective study of the clinic in Leuven were presented at the European Congress on Oncogynaecology in Athens in the end of 2019, as well as a publication in the journal "Gynaecological Oncology" from 2015. Fourteen patients with CC with sizes of up to $4 \mathrm{~cm}$ - in which neoadjuvant chemotherapy was administered with subsequent conization - were included in the study. Sentinel lymph node dissection before NCT was performed in all of them. Only patients negative for lymph node metastases were included in the study. The results updated to the year 2017 demonstrate the following: 13 out of 14 patients responded to neoadjuvant chemotherapy; 11 out of 14 patients had complete histological response after NCT; 14 pregnancies occurred with the delivery of 10 liveborn children (all of them after the $32^{\text {nd }}$ gestational week), and 4 spontaneous abortions in the first trimester; after a follow-up of 5.8 years, 1 relapse occurred, which was treated successfully by means of hysterectomy and radiotherapy; not a single patient developed cervical stenosis after the conization (oral contraceptives were prescribed with the purpose of monthly menstruation) [20].

Novelties in fertility preservation surgery in hormone-producing tumours (sex cord tumours (SCT)), and more specifically granulosa cell tumours of juvenile type.

1. FPS in malignant ovarian tumours is defined as follows: surgery preserving the uterus or ovaries. It includes bilateral salpingo-oophorectomy (BSO) with preservation of uterus and unilateral salpingo-oophorectomy (USO).

2. Indications for FPS in ovarian neoplasms include the following: FPS can be applied safely in patients with IA and IC stages of low-grade ovarian cancer
(LGSOC). A mandatory condition in these cases is the complete determination of the stage - peritoneal and retroperitoneal (pelvic and paraaortic lymph node dissection up to renal blood vessels). FPS has no place in invasive ovarian cancer of more than first stage of FIGO (with completely determined stage), as well as in every single stage of high-grade serous ovarian cancer (HGSOC), clear cell and small cell carcinoma. FPS after first stage (with residual tumour inclusively) can be applied as an exception in germ cell tumours [21].

3. Current aspects of FPS in granulosa cell tumours: according to the tissue from which they arise, the World Health Organization divides ovarian tumours into the following: epithelial tumours $-65 \%$, germ cell tumours $-15 \%$, sex cord tumours $-10 \%$, metastatic tumours $-5 \%$, others, unclassifiable.

Sex-cord tumours (SCTs) are mainly hormoneproducing tumours. Two types of tumours are basically presented: granulosa cell tumours and SertoliLeydig cell tumours. The latter are not indicated for FPS because of the more aggressive biology of the tumour [22].

Granulosa cell tumours (GCTs) are encountered rarely - they constitute $3-5 \%$ of all malignant ovarian tumours. There are 2 basic types of these tumours according to age, and clinical and pathological characteristics: adult type - which affects women in the fifth decade (95\%), and juvenile type - which affects girls between around puberty and up to 30 years of age (5\%). They are hormone-producing ovarian tumours, which determines the symptoms in making a diagnosis: vaginal bleeding, precocious puberty, menstrual disorders, hirsutism/virilism, abdominal pain, or heaviness. Hanley described GCTs as formations of large volume, most frequently of stage IA - cysts or solid tumours with preserved capsule. The most important prognostic factors are the stage and avoidance of rupture of the formation during operation (or the presence of malignant ascites). Thus, in the first stage, the overall survival rate is $90 \%$, while for the other stages it varies from $30 \%$ to $50 \%$ [22].

FPS in GCTs means preserving a part of one of the ovaries and of the uterus. In these cases, the points of reference for observations, studies, and advisability of organ-preserving techniques are the oncological results (overall and disease-free survival rate), reproductive results (spontaneous conceptions), and oncological safety of in vitro fertilization (IVF). The largest study on FPS in GCT in stage I was conducted by Bergamini, and the results were published in "Gynaecological Oncology" in 2019 [23]. The number of patients included in this study was 239 , while the average period of follow-up was 84 months. A high frequency of relapses - $24.3 \%$ - was recorded; the relapses were diagnosed more frequently in women with preserved reproductive organs $-37.2 \%$ - in comparison with $18 \%$ in the women subject to radical operation. Also, in the group with FPS the relapses were 
predominantly (82\%) local/pelvic. In more than 50\% of patients in the group with FPS, overall determination of stage was not performed, and that was the reason for the high number of relapses in stage IA. The conclusions drawn from the study by Bergamini are as follows: late relapses are possible (after up to 5 years) in young patients; the relapses are mainly in the pelvis; long-term follow-up after FPS is necessary; and the determination of the surgical stage is of essential significance. Based on this study, the main principles of FPS in GCT were brought out: patients in stages IA, IB, and IC1 are eligible for this type of surgery; in these cases, performing endometrial curettage and complete determination of the surgical stage are imposed - washes, peritoneal biopsies, pelvic and paraaortic lymph node dissection, omentectomy, and biopsy of the contralateral ovary. In the first clinical stage and in planned unilateral adnexectomy, caution has to be increased towards prevention of rupture of the cyst. Endometrial curettage before the operative intervention is recommended in connection with the planned preservation of the uterus, because the intraoperative express histological consultation is not accurate; a limiting factor for FPS is the state of more than first stage according to FIGO. If the requirements for FPS are met, and the stage is not above IC1, no adjuvant chemotherapy is required.

It is important after organ preservation operation to guarantee the oncological safety of a possible in $v i$ tro fertilization (IVF) procedure. Ovarian stimulation is an element of assisted reproductive technologies. Ovarian stimulation in GCT is not recommended because follicle-stimulating hormone (FSH) receptors are found in GCT [24], while the stimulation is related to exposure to high doses of FSH. Besides, there is in vitro evidence for the connection between the exposure to gonadotropins and development of granulosa cell tumours [25]. Another study points out that high concentrations of FSH are oncogenic for granulosa cells [26]. According to contemporary recommendations in GCT of stage IA, the indications for ovarian stimulation should be discussed by a multidisciplinary team of experts case by case, while in tumours above stage IA or other histological types (Sertoli-Leydig cell tumours), ovarian stimulation is contraindicated [27, 28].

The frequency of pregnancy, births, and recurrences after pregnancy is not well known because of the rareness of these tumours. The information in medical literature is insufficient.

\section{FPS in epithelial borderline ovarian tumours (BOTs)}

BOTs have some specific histological differences compared to benign and malignant ovarian tumours: they have higher epithelial proliferation and more variable nuclear atypia than benign lesions, and they have no stromal invasion, in contrast to carcinomas
[29]. The most common types are serous or mucinous and rarely clear-cell, endometrioid, and Brenner (transitional-cell) tumours.

About $30 \%$ of patients with BOTs are diagnosed in reproductive age (below 40 years of age) [30], and that is why the question of preservation of fertility is so important for them.

When stage I is concerned, adnexectomy or cystectomy is performed; adnexectomy is preferable because there is lower risk of relapse [31]. Cystectomy is performed in bilateral tumours or in patients with only 1 ovary. The risk of recurrence after unilateral cystectomy, unilateral salpingo-oophorectomy, or bilateral unilateral salpingo-oophorectomy is $30.3 \%, 11 \%$, and $1.7 \%$, respectively [32]. These patients can conceive spontaneously, while it is desirable for this to happen as soon as possible after operative intervention [33]. The pregnancy rate in these patients varies between $30 \%$ and $80 \%[34,35]$. Some authors did not find differences in pregnancy rates according to surgical approach (open versus laparoscopy) or type of surgery (unilateral cystectomy versus unilateral salpingo-oophorectomy) [36].

It is assumed that the use of assisted reproductive techniques is safe in such patients. The stimulation of the ovaries in women BOTs is relatively safe, and extraction of the ovum is possible before the operation [37].

Serous BOTs may present implants on peritoneal surfaces [38]. In rare cases, these implants can invade underlying tissue and then, according to the 2014 WHO (World Health Organization) Classification of Tumours of Female Reproductive Organs, BOTs should be considered as low-grade serous carcinoma $[29,39]$. According to the recommendations of ESGO from 2019, FPS in serous BOTs is applicable in I-III stage according to FIGO [40].

In these cases, the surgical removal of extraovarian implants is of great significance. In these cases, adjuvant therapy is not recommended. The optimal time till the occurrence of pregnancy was not found, but the long-term observation of the preserved ovary and peritoneal implants (by means of imaging diagnostics) are of great significance, especially before planned pregnancy (IVF). In this sense, the safety of IVF procedures was not found. The current publications confirm the practical applicability of these recommendations [37, 41].

\section{Conclusions}

The abdominal radical trachelectomy - from one side - and neoadjuvant chemotherapy followed by conization or simple trachelectomy - from the other - have identical oncological results in cancer CC with sizes of up to $4 \mathrm{~cm}$ and negative lymph nodes. NCT followed by conization/simple trachelectomy is associated with higher frequency of pregnancies and lower risk of incomplete carrying of the foetus, compared 
to radical trachelectomy. The sentinel (indocyanine green, ICG) pelvic lymph node dissection in patients with CC of IB2 stage (FIGO classification of 2018) selects candidates for FPS.

Granulosa cell tumours of juvenile type can occur in young girls. The prognosis depends on the stage, and FPS is not recommended in stages above IC because relapses with very poor prognosis may occur. In FPS adequate determination of the surgical stage is of great significance. Ovarian stimulation is contraindicated in GCT of stage IC.

FPS in BOTs of stage I according to FIGO classification is applicable and safe for the patients. Women with serous BOTs stage II-III are also appropriate candidates for FPS, but radical surgical excision of the extraovarian implants is recommended.

\section{Conflict of interest}

The authors declare no conflict of interest.

\section{References}

1. Sonoda Y, Abu-Rustum NR, Gemignani ML, Chi DS, Brown CL, Poynor EA, Barakat RR. A fertility-sparing alternative to radical hysterectomy: how many patients may be eligible? Gynecol Oncol 2004; 95: 534-538.

2. Plante M, Renaud MC, François H, Roy M. Vaginal radical trachelectomy: an oncologically safe fertility-preserving surgery. An updated series of 72 cases and review of the literature. Gynecol Oncol 2004; 94: 614-623.

3. Zusterzeel PL, Pol FJ, van Ham M, Zweemer RP, Bekkers RL, Massuger LF, Verheijen RH. Vaginal radical trachelectomy for early-stage cervical cancer: increased recurrence risk for adenocarcinoma. Int J Gynecol Cancer 2016; 26: 1293-1299.

4. Cibula D, Pötter R, Planchamp F, Avall-Lundqvist E, Fischerova D, Meder CH, Köhler C, Landoni F, Lax S, Lindegaard JC, Mahantshetty U, Mathevet P, McCluggage WG, McCormack M, Naik R, Nout R, Pignata S, Ponce J, Querleu D, Raspagliesi F, Rodolakis A, Tamussino K, Wimberger P, Raspollini MR. The European Society of Gynaecological Oncology/European Society for Radiotherapy and Oncology/European Society of Pathology Guidelines for the management of patients with cervical cancer. Int J Gynecol Cancer 2018; 28: 641-655.

5. Smith JR, Boyle DC, Corless DJ, Ungar L, Lawson AD, Del Priore G, McCall JM, Lindsay I, Bridges JE. Abdominal radical trachelectomy: a new surgical technique for the conservative management of cervical carcinoma. $\mathrm{Br} \mathrm{J} \mathrm{Ob-}$ stet Gynaecol 1997; 104: 1196-1200.

6. Ungár L, Pálfalvi L, Hogg R, Siklós P, Boyle DC, Del Priore G, Smith JR. Abdominal radical trachelectomy: a fertility-preserving option for women with early cervical cancer. BJOG 2005; 112: 366-369.

7. Abu-Rustum NR, Sonoda Y, Black D, Levine DA, Chi DS, Barakat RR. Fertility-sparing radical abdominal trachelectomy for cervical carcinoma: technique and review of the literature. Gynecol Oncol 2006; 103: 807-813.

8. Wethington SL, Cibula D, Duska LR, Garrett L, Kim CH, Chi DS, Sonoda Y, Abu-Rustum NR. An international series on abdominal radical trachelectomy: 101 patients and 28 pregnancies. Int J Gynecol Cancer 2012; 22: 12511257.

9. Nishio H, Fujii T, Kameyama K, Susumu N, Nakamura M, Iwata T, Aoki D. Abdominal radical trachelectomy as a fertility-sparing procedure in women with early-stage cervical cancer in a series of 61 women. Gynecol Oncol 2009; 115: 51-55.

10. Li J, Li Z, Wang H, Zang R, Zhou Y, Ju X, Ke G, Wu X. Radical abdominal trachelectomy for cervical malignancies: surgical, oncological and fertility outcomes in 62 patients. Gynecol Oncol 2011; 121: 565-570.

11. Muraji M, Sudo T, Nakagawa E, Ueno S, Wakahashi S, Kanayama S, Yamada T, Yamaguchi A, Fujiwara K, Nishimura R. Type II versus type III fertility-sparing abdominal radical trachelectomy for early-stage cervical cancer: a comparison of feasibility of surgical outcomes. Int J Gynecol Cancer 2012; 22: 479-483.

12. Saso S, Ghaem-Maghami S, Chatterjee J, Naji O, Farthing A, Mason P, McIndoe A, Hird V, Ungar L, Del Priore G, Smith JR. Abdominal radical trachelectomy in West London. BJOG 2012; 119: 187-193.

13. Pareja FR, Ramirez PT, Borrero FM, Angel CG. Abdominal radical trachelectomy for invasive cervical cancer: a case series and literature review. Gynecol Oncol 2008; 111: 555-560.

14. Schneider A, Erdemoglu E, Chiantera V, Reed N, Morice P, Rodolakis A, Denschlag D, Kesic V. Clinical recommendation radical trachelectomy for fertility preservation in patients with early-stage cervical cancer. Int J Gynecol Cancer 2012; 22: 659-666.

15. Rob L, Skapa P, Robova H. Fertility-sparing surgery in patients with cervical cancer. Lancet Oncol 2011; 12: 192-200.

16. Plante M. Evolution in fertility-preserving options for early-stage cervical cancer: radical trachelectomy, simple trachelectomy, neoadjuvant chemotherapy. Int J Gynecol Cancer 2013; 23: 982-989.

17. Bentivegna E, Gouy S, Maulard A, Chargari C, Leary A, Morice P. Oncological outcomes after fertility-sparing surgery for cervical cancer: a systematic review. Lancet Oncol 2016; 17: e240-e253.

18. Bentivegna E, Maulard A, Pautier P, Chargari C, Gouy S, Morice P. Fertility results and pregnancy outcomes after conservative treatment of cervical cancer: a systematic review of the literature. Fertil Steril 2016; 106: 1195-1211.

19. Van Kol KGG, Vergeldt TFM, Bekkers RLM. Abdominal radical trachelectomy versus chemotherapy followed by vaginal radical trachelectomy in stage 1B2 (FIGO 2018) cervical cancer. A systematic review on fertility and recurrence rates. Gynecol Oncol 2019; 155: 515-521.

20. Salihi R, Leunen K, Van Limbergen E, Moerman P, Neven P, Vergote I. Neoadjuvant chemotherapy followed by large cone resection as fertility-sparing therapy in stage IB cervical cancer. Gynecol Oncol 2015; 139: 447-451.

21. Bentivegna E, Gouy S, Maulard A, Pautier P, Leary A, Colombo N, Morice P. Fertility-sparing surgery in epithelial ovarian cancer: a systematic review of oncological issues. Ann Oncol 2016; 27: 1994-2004.

22. Hanley KZ, Mosunjac MB. Practical review of ovarian sex cord-stromal tumors. Surg Pathol Clin 2019; 12: 587-620.

23. Bergamini A, Cormio G, Ferrandina G, Lorusso D, Giorda G, Scarfone G, Bocciolone L, Raspagliesi F, Tateo S, Cassani C, Savarese A, Breda E, De Giorgi U, Mascilini F, Candiani M, Kardhashi A, Biglia N, Perrone AM, S Pignata, Mangili G. 
Conservative surgery in stage I adult type granulosa cells tumors of the ovary: results from the MITO-9 study. Gynecol Oncol 2019; 154: 323-327.

24. Davy M, Torjesen PA, Aakavaag A. Demonstration of an FSH receptor in a functioning granulosa cell tumour. The effect of gonadotrophin treatment on its viability following transplantation to nude mice. Acta Endocrinol 1977; 85: 615-623.

25. Biskind G, Bernstein D, Gospe S. The effect of exogenous gonadotrophins on the development of experimental ovarian tumors in rats. Cancer Res 1953; 13: 216-220.

26. Willemsen W, Kruitwagen R, Bastiaans B, Hanselaar T, Rolland R. Ovarian stimulation and granulosa-cell tumour. Lancet 1993; 341: 986-988.

27. Yousefi Z, Khalilifar H, Jafarian AH, Davachi B, Seresh LM, Babapour N, Shirinzadeh L, Baradaran M. Granulosa-cell tumor after ovarian stimulation: a case report. Int J Reprod Biomed 2018; 16: 417-420.

28. Triantafyllidou O, Sigalos G, Oikonomou I, Vlahos N. Ovarian granulosa cell tumor and clomiphene citrate resistance. A case report and review of the literature. JBRA Assist Reprod 2018; 22: 381-384.

29. Prat J. Pathology of borderline and invasive cancers. Best Pract Res Clin Obstet Gynaecol 2017; 41: 15-30.

30. Buonomo B, Peccatori FA. Fertility preservation strategies in borderline ovarian tumor recurrences: different sides of the same coin. J Assist Reprod Genet 2020; 37: 1217-1219.

31. Daraï E, Fauvet R, Uzan C, Gouy S, Duvillard P, Morice P. Fertility and borderline ovarian tumor: a systematic review of conservative management, risk of recurrence and alternative options. Hum Reprod Update 2013; 19: 151-166.

32. Poncelet C, Fauvet R, Boccara J, Daraï E. Recurrence after cystectomy for borderline ovarian tumors: results of a French multicenter study. Ann Surg Oncol 2006; 13: 565-571.

33. Johansen G, Dahm-Kahler P, Staf C, Radestad AF, Rodriguez-Wallberg KA. Reproductive and obstetric outcomes with the overall survival of fertile aged women treated with fertility-sparing surgery for ovarian borderline tumors in Sweden: a prospective nationwide population-based study. Fertil Steril 2021; 115: 157-163.

34. Song T, Hun Choi C, Lee YY, Kim TJ, Lee JW, Bae DS, Kim BG. Oncologic and reproductive outcomes of cystectomy compared with oophorectomy as a treatment for borderline ovarian tumours. Hum Reprod 2011; 26: 20082014.

35. Fauvet R, Poncelet C, Boccara J, Descamps P, Fondrinier E, Daraï E. Fertility after conservative treatment for borderline ovarian tumors: a French multicenter study. Fertil Steril 2005; 83: 284-290.

36. Delle Marchette M, Ceppi L, Andreano A, Bonazzi CM, Buda A, Grassi T, Giuliani D, Sina F, Lamanna M, Bianchi T, Lissoni AA, Landoni F, Valsecchi MG, Fruscio R. Oncologic and fertility impact of surgical approach for borderline ovarian tumours treated with fertility sparing surgery. Eur J Cancer 2019; 111: 61-68.

37. Khiat S, Provansal M, Bottin P, Saias-Magnan J, MetzlerGuillemain C, Courbiere B. Fertility preservation after fertility-sparing surgery in women with borderline ovarian tumours. Eur J Obstet Gynecol Reprod Biol 2020; 253: $65-70$.
38. Maramai M, Barra F, Menada MV, Stigliani S, Moioli M, Costantini S, Ferrero S. Borderline ovarian tumours: management in the era of fertility-sparing surgery. Ecancermedicalscience 2020; 14: 1031.

39. Kurman RJ, Carcangiu ML, Herrington CS, Young RH. WHO Classification of Tumours of Female Reproductive Organs. IARC Press, Lyon 2014.

40. www.esgo.org (accessed on 20 December 2020).

41. Plett H, Harter P, Ataseven B, Heitz F, Prader S, Schneider S, Heikaus S, Fisseler-Eckhoff A, Kommoss F, Lax SF, Staebler A, Traut A, du Bois A. Fertility-sparing surgery and reproductive-outcomes in patients with borderline ovarian tumors. Gynecol Oncol 2020; 157: 411-417.

\section{Address for correspondence:}

Angel Danchev Yordanov PhD

Department of Gynaecological Oncology

Medical University Pleven

Pleven, Bulgaria

E-mail: angel.jordanov@gmail.com 